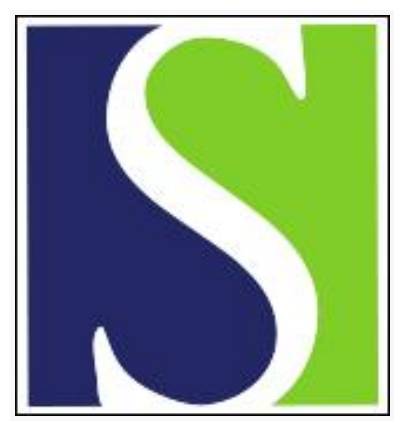

Scand J Work Environ Health 1985;11(4):295-300

https://doi.org/10.5271/sjweh.2225

Issue date: Aug 1985

Monitoring of urinary mutagenicity in workers exposed to low doses of 2,4,7-trinitro-9-fluorenone.

by Crebelli R, Aquilina G, Falcone E, Carere A, Caperle M, Crespi M, Zito $\mathrm{R}$

This article in PubMed: www.ncbi.nlm.nih.gov/pubmed/3903982 


\title{
Monitoring of urinary mutagenicity in workers exposed to low doses of 2,4,7-trinitro-9-fluorenone
}

\author{
by Riccardo Crebelli, MSc, ${ }^{1}$ Gabriele Aquilina, MSc, ${ }^{1}$ Emiliana Falcone, MSc, ${ }^{1}$ \\ Angelo Carere, MSc, ${ }^{1}$ Marco Caperle, MD, ${ }^{2}$ Massimo Crespi, MD, ${ }^{2}$ Romano Zito, $\mathrm{MD}^{2}$
}

\begin{abstract}
CREBELLI R, AQUILINA G, FALCONE E, CARERE A, CAPERLE M, CRESPI M, ZITO R. Monitoring of urinary mutagenicity in workers exposed to low doses of 2,4,7-trinitro-9-fluorenone. Scand $J$ Work Environ Health 11 (1985) 295-300. A monitoring of the urinary mutagenicity in workers occupationally exposed to low doses of 2,4,7-trinitro-9-fluorenone (TNF) was undertaken. Urine concentrate of 22 exposed workers (11 smokers and 11 nonsmokers) and 18 presumedly unexposed workers ( 7 smokers and 11 nonsmokers) were assayed for mutagenicity in Salmonella typhimurium strain TA98 with the plate incorporation technique. In this test system none of the urine concentrate was effective as a mutagen, either in the absence or presence of S9. Fifteen urine samples ( 8 from exposed workers, 7 from referents) were also tested in the microtiter fluctuation assay. With this technique smoking habits were significantly related to urinary mutagenicity in tests performed with metabolic activation. In neither case however was the association between presumed exposure and urinary mutagenicity significant. These results were evaluated on the basis of urinary mutagenicity data obtained from rats exposed to TNF by different routes. It was shown that the observed urinary mutagenicity accounts for a minor fraction of the administered TNF dose (about 0.1 to $0.2 \%$, depending on the route of exposure); thus it is possible that low-level exposure to TNF could escape detection by urinary mutagenicity monitoring.
\end{abstract}

Key terms: biological monitoring, occupational safety.

2,4,7-Trinitro-9-fluorenone (TNF) is known to exert remarkable mutagenic activity in several genetic systems, possibly following the esterification of hydroxylamino intermediates to strong electrophilic species (15). Mutagenicity studies have shown that TNF is a powerful direct mutagen in prokaryotes $(13,15,16,17)$, a phenomenon suggesting the involvement of bacterial nitroreductases in its metabolic activation. TNF has also been shown to induce unscheduled synthesis of deoxyribonucleic acid in rat hepatocytes in vitro (16), sister-chromatid exchanges in Chinese hamster ovary cells, and gene mutations in mouse lymphoma cells, with, as well as without, metabolic activation (17). These data, apart from indicating a possible genetic risk, suggest that TNF could be endowed with carcinogenic characteristics. Thus far no thoroughly long-term study has been performed to investigate TNF carcinogenic potential. However, a report by Huggins \& Yang (8) indicated an increase in the incidence of mammary tumors in rats after a single dose administered orally.

On the basis of these data, the possible genotoxic risks related to the presence of TNF in the photoconductor of some photocopying and printing systems were recently debated in Italy. Analytical measurement showed in fact the presence of TNF residues in both printed and photocopied sheets $(0.4$ to $4 \mu \mathrm{g}$ in

\footnotetext{
1 Istituto Superiore di Sanità, Rome, Italy.

2 Istituto Regina Elena, Rome, Italy.
}

Reprint requests to: Dr R Crebelli, Laboratorio di Tossicologia Applicata, Istituto Superiore di Sanità, Viale Regina Elena, 299-00161 Rome, Italy.
$21 \times 27-\mathrm{cm}$ sheets) and in the air surrounding operating machines ( 0 to $\left.0.4 \mu \mathrm{g} / \mathrm{m}^{3}\right)$ (9), the possibility of chronic exposure to low doses of TNF thus being indicated for workers charged with the use of such photocopying and printing systems.

In the past few years urinary mutagenicity studies have been successfully used for the surveillance of exposure to genotoxic agents in occupational environments $(3,4,10,11,14)$. This approach was chosen by us in a study carried out in a group of office workers suspected to be occupationally exposed to low doses of TNF. The results obtained are evaluated in the present report and discussed on the basis of the urinary excretion of mutagens observed in rats dosed with TNF by different routes.

\section{Materials and methods}

\section{Subjects}

The study was carried out in 1981 and 1982 . The workers suspected to be exposed to TNF were 22 white males (11 smokers and 11 nonsmokers), employed in the use of IBM Printing System 3800 in a well-ventilated room of a bank (approximate volume $\left.100 \mathrm{~m}^{3}\right)$. The system was in use $24 \mathrm{~h}$ a day. Workshifts were $8 \mathrm{~h}$ a day, $5 \mathrm{~d}$ a week. Urine samples were collected in the morning after at least three workdays. Eighteen white males (7 smokers and 11 nonsmokers) working in the same bank but coming in contact with the printing system only occasionally served as presumedly unexposed referents. Actually, whether these subjects were completely unexposed to 
TNF is questionable. In fact a generalized exposure of the whole workforce to much lower amounts of TNF could not be ruled out because of a possible air exchange caused between rooms by the air conditioning system. Smoking habits, diet, and recent drug consumption were recorded before the collection of urine.

\section{Animal treatments}

Male Sprague-Dawley rats weighing about $200 \mathrm{~g}$ received TNF in $0.5 \mathrm{ml}$ of corn oil (controls received vehicle alone) by intragastric administration, or the compound was applied percutaneously. In the case of the latter TNF, dissolved in $2.5 \mathrm{ml}$ of acetone, was gently rubbed onto the dorsal hair. After $1 \mathrm{~h}$ the chemical was carefully removed with repeated washing of the hair with the same solvent. During the treatment precautions were taken to avoid the possible ingestion of the chemical.

\section{Urine concentration}

Human urine was immediately frozen after collection and stored frozen in the dark until concentration. The concentrates were prepared as follows: urine was thawed at room temperature, centrifuged, and passed over XAD-2 resin $(8 \mathrm{~g}$ in $30 \times 1.5-\mathrm{cm} \mathrm{Bio-Rad} \mathrm{glass}$ Econo columns) with a max flux of $3 \mathrm{ml} / \mathrm{min}$. Afterwards the columns were washed with $500 \mathrm{ml}$ of deionized water and eluted with $20 \mathrm{ml}$ of acetone and $20 \mathrm{ml}$ of acetone : water (1:1, volume : volume). All

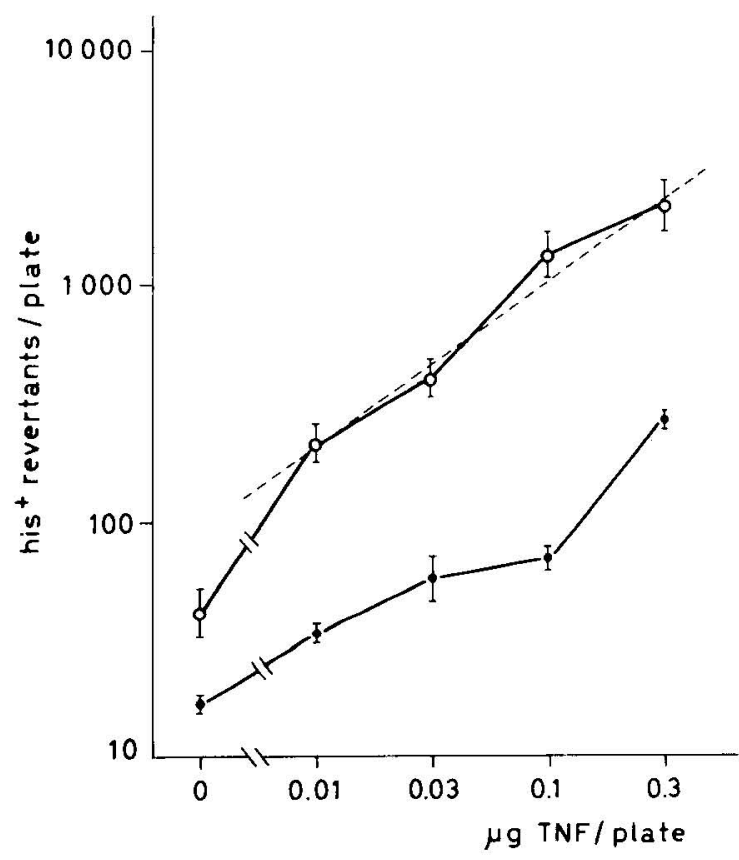

Figure 1. Mutagenic activity of 2,4,7-trinitro-9-fluorenone (TNF) in the plate incorporation assay with Salmonella typhimurium strain TA98 - Average and standard deviation from three plates. (Open symbols = without $\$ 9$, closed symbols $=$ with S9) the operations were performed at $4^{\circ} \mathrm{C}$. The eluate was lyophilized, and the residue extracted four times with $1 \mathrm{ml}$ of dichloromethane. The extract was vacuum evaporated, and the residue dissolved in dimethylsulfoxide.

Rat urine was collected in metabolic cages where the animals had free access to water and food (standard chow, free of contaminants). The urine was passed over Bio-Rad glass Econo columns $(0.7 \times 10 \mathrm{~cm})$ filled with $0.7 \mathrm{~g}$ of XAD-2 resin. The columns were washed with $6 \mathrm{ml}$ of water and then eluted with $3 \mathrm{ml}$ of acetone. The eluate was vacuum evaporated at $40^{\circ} \mathrm{C}$, extracted with $1 \mathrm{ml}$ of dichloromethane, and vacuum evaporated again. The residue was dissolved in $1 \mathrm{ml}$ of dimethylsulfoxide.

\section{Mutagenicity assays}

Salmonella typhimurium strain TA98 was kindly supplied by Prof BN Ames, University of Berkeley, Berkeley, California, the United States. The selection of $h i s^{+}$revertants in the plate incorporation assay was performed according to the procedure described by Ames et al (1). The microtiter fluctuation assay was as described by Gatehouse (5) and Gatehouse \& Delow (6). Liver microsomal fractions (S9) were obtained from male Sprague-Dawley rats pretreated with Aroclor 1254 (Monsanto). Protein concentration, as determined by the Lowry method with bovine serum albumin as the standard, was $40 \mathrm{mg} / \mathrm{ml}$. Escherichia coli $\beta$-glucuronidase ( $1000 \mu$ /plate, type VII, Sigma) was added for the assay of urine concentrates in the plate incorporation assay; $200 \mu / \mathrm{ml}$ was used in the microtiter fluctuation test. Positive controls were included to check both strain sensitivity and enzymatic activity, as well as to act as routine controls of samples and $\mathrm{S} 9$ sterility.

\section{Chemicals}

2-Aminoanthracene and 4-nitro-o-phenylendiamine, routinely used as positive controls, were obtained from Fluka $\mathrm{AG}$ and Sigma Chem Co, respectively. TNF was provided by ICN Pharmaceuticals, New York, the United States.

\section{Results}

Figure 1 shows that TNF was highly mutagenic when tested in $S$ typhimurium TA98 by the plate incorporation technique. Such activity was notably reduced when tests were carried out in the presence of S9.

Urine concentrates of both exposed workers (11 smokers and 11 nonsmokers) and presumedly unexposed referents ( 7 smokers and 11 nonsmokers) were assayed for their mutagenicity in the same test system. Amounts of concentrates equivalent to 2.5 and $10 \mathrm{ml}$ of unprocessed urine were assayed in triplicate. Figure 2 shows that none of the urine concentrates assayed 

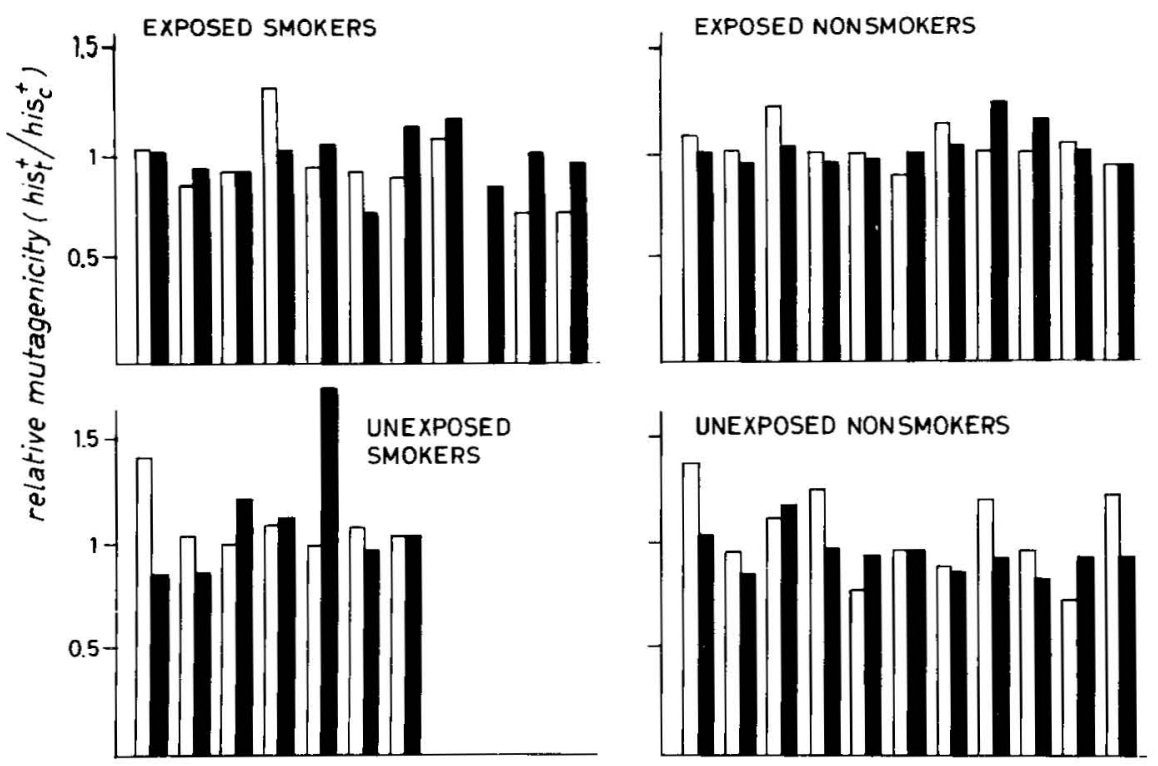

Figure 2. Monitoring of urinary mutagenicity in the plate incorporation assay with Salmonella typhimurium strain TA98. The data shown in the figure were obtained from assays of concentrate amounts corresponding to $10 \mathrm{ml}$ of urine in triplicate $(2.5 \mathrm{ml}$ in three cases because of the cytotoxicity of the samples); the standard deviation never exceeded $25 \%$ of the average values. Each bar represents a single sample. Solvent controls gave means of 25 (SD 5) and 39 (SD 8) revertants/plate ( $N=30$ ) without and with S9, respectively. 4-Nitro-o-phenylendiamine (5 $\mu$ g/plate), used as a positive control without S9, gave a mean of 371 (SD 77) revertants/plate $(N=28)$. In the presence of $S 9$, 2-aminoanthracene (1 $\mu$ g/plate) gave a mean of 543 (SD 160) revertants/plate $(\mathrm{N}=29)$. (Open bars $=$ without $S 9$; closed bars $=$ with $S 9$ )

Table 1. Monitoring of urinary mutagenicity - Results of the microtiter fluctuation assay with Salmonella typhimurium strain TA98. [All tests were performed with Escherichia coli $\beta$-glucuronidase $(200 \mu / \mathrm{ml})$.]

\begin{tabular}{|c|c|c|c|c|c|c|c|c|c|}
\hline \multirow{3}{*}{ Subject } & \multirow{3}{*}{$D_{o s e}^{a}$} & \multicolumn{4}{|c|}{ Exposed workers } & \multicolumn{4}{|c|}{ Unexposed referents } \\
\hline & & \multicolumn{2}{|c|}{ Nonsmokers } & \multicolumn{2}{|c|}{ Smokers } & \multicolumn{2}{|c|}{ Nonsmokers } & \multicolumn{2}{|c|}{ Smokers } \\
\hline & & $-S 9$ & $+S 9$ & $-\$ 9$ & $+\mathrm{S} 9$ & $-\$ 9$ & $+\mathrm{S} 9$ & $-\$ 9$ & +59 \\
\hline 1 & $\begin{array}{r}-5 \\
10 \\
20\end{array}$ & $\begin{array}{c}9^{b} \\
7 \\
16 \\
12\end{array}$ & $\begin{array}{l}5 \\
8 \\
8 \\
8\end{array}$ & $\begin{array}{l}11 \\
15 \\
11 \\
15\end{array}$ & $\begin{array}{l}21 \\
26 \\
31 \\
35^{\star}\end{array}$ & $\begin{array}{r}9 \\
12 \\
11 \\
13\end{array}$ & $\begin{array}{l}5 \\
5 \\
2 \\
3\end{array}$ & $\begin{array}{r}9 \\
10 \\
10 \\
10\end{array}$ & $\begin{array}{r}5 \\
7 \\
10 \\
3\end{array}$ \\
\hline 2 & $\begin{array}{c}- \\
2.5 \\
5 \\
10\end{array}$ & $\begin{array}{r}5 \\
10 \\
11 \\
5\end{array}$ & $\begin{array}{l}4 \\
6 \\
7 \\
8\end{array}$ & $\begin{array}{c}5 \\
8 \\
14^{\star} \\
12^{\star}\end{array}$ & $\begin{array}{c}4 \\
8 \\
4 \\
11^{\star}\end{array}$ & $\begin{array}{c}5 \\
7 \\
12^{*} \\
10\end{array}$ & $\begin{array}{l}4 \\
7 \\
7 \\
4\end{array}$ & $\begin{array}{r}5 \\
6 \\
7 \\
11\end{array}$ & $\begin{array}{c}4 \\
9 \\
9 \\
12^{\star}\end{array}$ \\
\hline 3 & $\begin{array}{r}-5 \\
10\end{array}$ & $\begin{array}{l}10 \\
12 \\
10\end{array}$ & $\begin{array}{r}11 \\
15 \\
9\end{array}$ & $\begin{array}{r}10 \\
8 \\
11\end{array}$ & $\begin{array}{l}11 \\
23^{*} \\
14\end{array}$ & $\begin{array}{l}10 \\
12 \\
38^{* *}\end{array}$ & $\begin{array}{r}11 \\
8 \\
12\end{array}$ & $\begin{array}{c}10 \\
9 \\
22^{*}\end{array}$ & $\begin{array}{r}11 \\
9 \\
11\end{array}$ \\
\hline 4 & $\begin{array}{r}-5 \\
10\end{array}$ & $\begin{array}{r}10 \\
9 \\
16\end{array}$ & $\begin{array}{r}11 \\
8 \\
18\end{array}$ & $\begin{array}{r}10 \\
9 \\
15\end{array}$ & $\begin{array}{l}11 \\
13 \\
12\end{array}$ & $\begin{array}{l}\ldots \\
\ldots \\
\cdots\end{array}$ & $\begin{array}{l}\ldots \\
\ldots \\
.\end{array}$ & $\begin{array}{l}10 \\
10 \\
19^{\star}\end{array}$ & $\begin{array}{l}11 \\
21^{*} \\
23^{*}\end{array}$ \\
\hline
\end{tabular}

a The equivalent volume of unconcentrated urine assayed is shown; different doses were assayed on the basis of the urinary volume available.

b The number of positive wells out of 96 is shown; 4-nitro-0-phenylendiamine $(0.25 \mu \mathrm{g} / \mathrm{ml})$ and 2-aminoanthracene $(0.2 \mu \mathrm{g} / \mathrm{ml})$, used as positive controls, gave means of 90 (SD 3) and 93 (SD 2) positive wells, respectively, for four experiments.

* $p<0.05,{ }^{* *} p<0.01$ (chi-square test).

was effective as a mutagen, ie, able to double the spontaneous number of is $^{+}$revertants, either in the absence or in the presence of metabolic activation.

Fifteen urine samples ( 8 from exposed men and 7 from referents) were also assayed by the microtiter fluctuation test. Data in table 1, synthesized in figure 3 , show that, in the absence of metabolic activation, a few urine concentrates were significantly mutagenic; however their distribution (1 among the exposed,
4 among the referents) showed no relationship with the presumed exposure. On the other hand TNF amounts as low as $0.15 \mathrm{ng} / \mathrm{ml}$ gave a highly significant response under the same experimental conditions (figure 4). In the presence of S9, five out of eight urine concentrates of both the unexposed and exposed smokers were mutagenic, whereas nonsmokers' urine was completely inactive. This prevalence of mutagenic samples among smokers' urine was sta- 


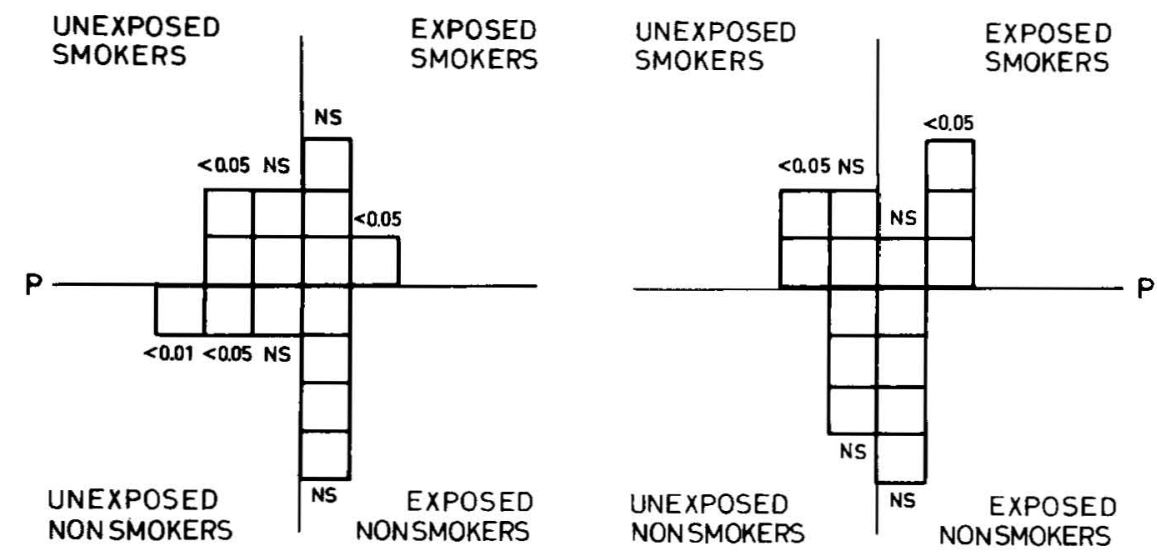

Figure 3. Monitoring of urinary mutagenicity in the microtiter fluctuation test with Salmonella typhimurium strain TA98. The distribution of mutagenic activity among the investigated subjects is shown. Each square represents one individual sample (on the left, without S9; on the right, with S9). Data from table 1.

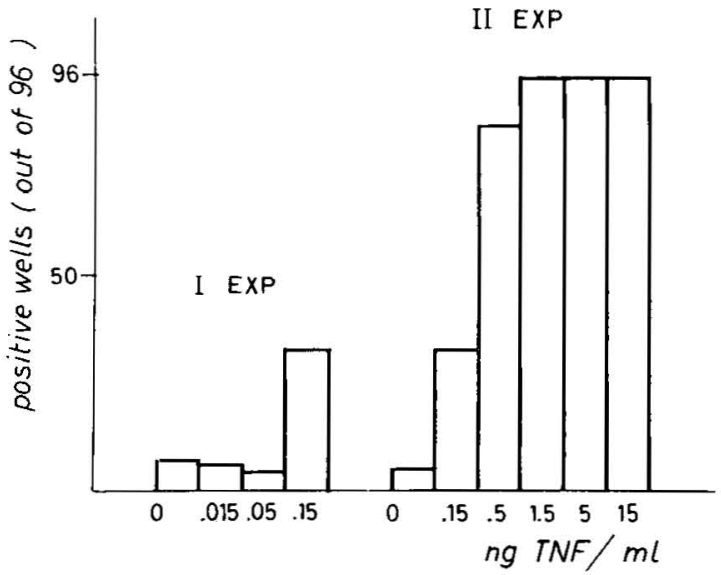

Figure 4. Mutagenic activity of 2,4,7-trinitro-9-fluorenone (TNF) in the microtiter fluctuation test without S9 with Salmonella typhimurium strain TA98. 4-Nitro-o-phenylendiamine $(0.25 \mu \mathrm{g} / \mathrm{ml})$, used as a positive control, gave 89 out of 96 positive wells in both experiments.

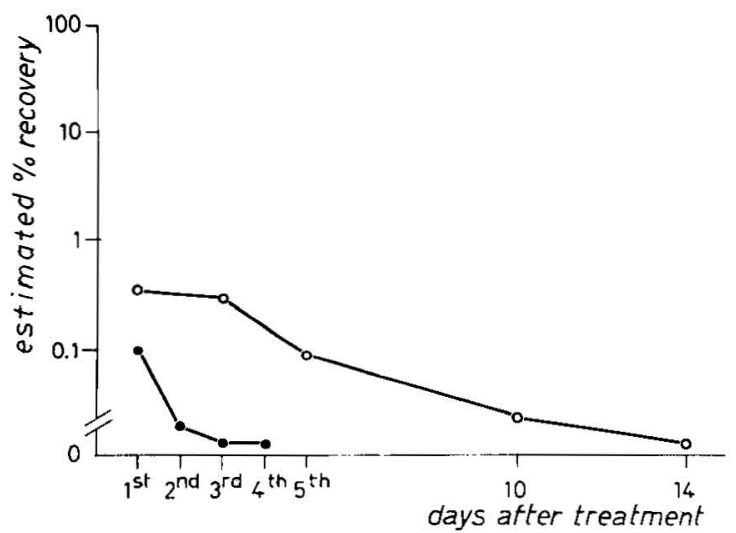

Figure 5. Estimated percentage of recovery of 2,4,7-trinitro-9fluorenone (TNF) in urine of rats treated by gavage (closed symbols) or percutaneously (open symbols) with TNF. Data from tables 2 and 3 and figure 2 .
Table 2. Mutagenicity of rat urine concentrate after the intragastric administration of 2,4,7-trinitro-9-fluorenone (TNF) - Plate incorporation assay with Salmonella typhimurium strain TA98. ${ }^{a}$

\begin{tabular}{|c|c|c|c|}
\hline \multirow{2}{*}{ Days after treatment } & \multirow{2}{*}{$\begin{array}{c}\text { Microliter of } \\
\text { urine concentratel } \\
\text { plate }{ }^{b}\end{array}$} & \multicolumn{2}{|c|}{$\begin{array}{c}\text { His }+ \text { revertants/ } \\
\text { plate }^{c}\end{array}$} \\
\hline & & Mean & SD \\
\hline Control untreated & $1 \overline{00}$ & $\begin{array}{l}60 \\
35\end{array}$ & $\begin{array}{r}13 \\
9\end{array}$ \\
\hline First day & $\begin{array}{r}-1 \\
3 \\
10 \\
30 \\
100\end{array}$ & $\begin{array}{r}60 \\
46 \\
84 \\
192 \\
324 \\
717\end{array}$ & $\begin{array}{r}13 \\
5 \\
7 \\
26 \\
80 \\
4\end{array}$ \\
\hline Second day & $\begin{array}{r}\overline{10} \\
30 \\
100\end{array}$ & $\begin{array}{l}64 \\
56 \\
60 \\
67\end{array}$ & $\begin{array}{r}10 \\
9 \\
2 \\
6\end{array}$ \\
\hline Positive controld & - & 552 & 26 \\
\hline
\end{tabular}

a Tests were performed with the addition of Escherichia coli B-glucuronidase $(1000 \mu /$ plate) without metabolic activation by liver S9. Two male Sprague-Dawley rats $(200 \mathrm{~g}$ body weight) received $1 \mathrm{mg}$ of TNF in $0.5 \mathrm{ml}$ of corn oil; controls received vehicle alone.

b Twenty-four-hour urine was concentrated as described in the Materials and Methods section, and the dry residue dissolved in $1 \mathrm{ml}$ of dimethylsulfoxide.

c Average and standard deviation from three plates.

d 4-Nitro-0-phenylendiamine ( $5 \mu \mathrm{g} / \mathrm{plate}$ ).

tistically significant $(5 / 8$ versus $0 / 7, p<0.001$, Fisher's "exact" test).

Experiments performed to evaluate urinary mutagenicity in rats exposed to TNF showed a low mutagenic activity in urine collected over the first $24 \mathrm{~h}$ after a single intragastric administration of $1 \mathrm{mg}$ of the chemical (table 2). On the other hand, percutaneous application of TNF caused the appearance of moderate urinary mutagenicity, which lasted for at least three weeks in the case of the higher treatment (table 3). From a comparison of the mutagenic activity of rat urine concentrates with the in vitro activity of 
Table 3. Mutagenicity of rat urine concentrates after topical application of 2,4,7-trinitro-9-fluorenone (TNF) - Plate incorporation assay with Salmonella typhimurium strain TA98. ${ }^{a}$

\begin{tabular}{|c|c|c|c|c|c|}
\hline \multirow{3}{*}{ Days after treatment } & \multirow{3}{*}{$\begin{array}{l}\text { Microliters of urine } \\
\text { concentrate/plate }\end{array}$} & \multicolumn{4}{|c|}{ Treatment $^{c}$} \\
\hline & & \multicolumn{2}{|c|}{$1 \mathrm{mg}$ TNF } & \multicolumn{2}{|c|}{$10 \mathrm{mg} \mathrm{TNF}$} \\
\hline & & Mean & SD & Mean & SD \\
\hline Control untreated & $\overline{100}$ & $\begin{array}{l}22 \\
24\end{array}$ & $\begin{array}{l}6 \\
6\end{array}$ & $\begin{array}{l}22 \\
25\end{array}$ & $\begin{array}{l}6 \\
5\end{array}$ \\
\hline Days $1-2$ & $\begin{array}{r}- \\
10 \\
30 \\
60\end{array}$ & $\begin{array}{r}25 \\
330 \\
873 \\
1463\end{array}$ & $\begin{array}{r}6 \\
. \\
18 \\
119 \\
62\end{array}$ & $\begin{array}{r}25 \\
704 \\
1629 \\
2334 \\
\ldots\end{array}$ & $\begin{array}{r}6 \\
33 \\
158 \\
120 \\
. .\end{array}$ \\
\hline Days $3-4$ & $\begin{array}{r}- \\
10 \\
30 \\
60\end{array}$ & \begin{tabular}{r}
34 \\
\hdashline 3 \\
143 \\
238
\end{tabular} & $\begin{array}{r}6 \\
\because \\
8 \\
6 \\
18\end{array}$ & $\begin{array}{r}34 \\
823 \\
1383 \\
1633 \\
\ldots\end{array}$ & $\begin{array}{r}6 \\
27 \\
104 \\
288 \\
. .\end{array}$ \\
\hline Days $5-6$ & $\begin{array}{r}- \\
3 \\
10 \\
30 \\
100\end{array}$ & $\begin{array}{r}23 \\
\times \\
53 \\
96 \\
263\end{array}$ & $\begin{array}{r}2 \\
\because 5 \\
22 \\
6\end{array}$ & $\begin{array}{r}23 \\
281 \\
812 \\
1075 \\
\ldots\end{array}$ & $\begin{array}{r}2 \\
26 \\
113 \\
221 \\
\ldots\end{array}$ \\
\hline Days $11-12$ & $\begin{array}{r}\overline{10} \\
30 \\
60 \\
100\end{array}$ & $\begin{array}{r}39 \\
\times \\
62 \\
76 \\
106\end{array}$ & $\begin{array}{r}5 \\
18 \\
14 \\
9\end{array}$ & $\begin{array}{r}39 \\
87 \\
164 \\
268 \\
.\end{array}$ & $\begin{array}{r}5 \\
11 \\
10 \\
59 \\
.\end{array}$ \\
\hline Days $13-14$ & $\begin{array}{r}\overline{10} \\
30 \\
60 \\
100\end{array}$ & $\begin{array}{l}29 \\
3 \\
33 \\
48 \\
61\end{array}$ & $\begin{array}{r}3 \\
10 \\
70 \\
7 \\
7\end{array}$ & $\begin{array}{r}29 \\
49 \\
94 \\
119 \\
. .\end{array}$ & $\begin{array}{r}3 \\
2 \\
15 \\
7 \\
. .\end{array}$ \\
\hline Days $20-21$ & $1 \overline{0}$ & $\begin{array}{l}32 \\
46\end{array}$ & $\begin{array}{l}6 \\
4\end{array}$ & $\begin{array}{r}32 \\
167\end{array}$ & $\begin{array}{r}6 \\
39\end{array}$ \\
\hline Days $27-28$ & $1 \overline{0}$ & $\begin{array}{l}33 \\
35\end{array}$ & $\begin{array}{l}5 \\
7\end{array}$ & $\begin{array}{l}33 \\
98\end{array}$ & $\begin{array}{r}5 \\
11\end{array}$ \\
\hline
\end{tabular}

a Two male Sprague-Dawley rats $(200 \mathrm{~g}$ body weight) were treated as described in the Materials and Methods section. Controls were topically treated with solvent alone. 4-Nitro-o-phenylendiamine, used as a positive control throughout the work $(5 \mu \mathrm{g} /$ plate), induced a mean of 382 (SD 47) revertants/plate $(N=18)$.

b Forty-eight-hour urine was concentrated as described in the Materials and Methods section, and the dry residue was dissolved in $1 \mathrm{ml}$ of dimethylsulfoxide.

c Average and standard deviation from three plates.

TNF, the biologically active fraction of the administered dose excreted in the urine can be tentatively calculated. Figure 5 shows that less than $0.1 \%$ of the administered TNF was excreted in the first $24 \mathrm{~h}$ after the intragastric administration and a greater amount (about twice) after the percutaneous application.

\section{Discussion}

The analysis of human body fluids for the presence of mutagenic compounds is a useful tool in the detection of exposure to identified or unknown genotoxic agents $(12,18)$. A limitation of this approach is that a negative result simply indicates that the previous exposure, if any, was below the lowest detectable level, and therefore such a result cannot be regarded as proof of no exposure.

With both the test systems used in this study the urinary mutagenicity did not show any relationship to the presumed TNF exposure. Plate incorporation assays gave negative results, whereas the positive results obtained by the microtiter fluctuation test were significantly related to smoking habits in tests performed with metabolic activation and unrelated to both smoking habits and occupational exposure in tests without metabolic activation (figure 3 ). In this last case the possible role of histidine-associated growth factors in XAD-2 concentrates (7) cannot be ruled out, although the dichloromethane extraction of eluates applied should preclude this possibility. Therefore, when the high mutagenic activity exerted by TNF in both the plate incorporation assay (figure 1) and the microtiter fluctuation test (figure 4) is taken into account, it may be inferred that the assayed urine concentrates contained less than $0.01 \mu \mathrm{g}$ of the chemical. The absence of mutagenic activity in the urine concentrate of smokers [20 (5 SD) cigarettes (medium tar content) / d] was not unexpected at all. Previous observations have shown in fact that, under our experimental conditions, the used amount of urine concentrate from smokers would have to be nearly doubled to produce an observable significant mutagenic activity (unpublished observations). On the other hand the urine amounts available for this 
study (50 to $100 \mathrm{ml}$ ) did not allow the assay of such amounts of concentrates.

The results of urine monitoring can be tentatively calibrated from urinary mutagenicity data obtained from experimental animals. It was observed that patterns of excretion differed remarkably depending on the route of exposure. After the intragastric administration the excretion of mutagens in urine disappeared in $24 \mathrm{~h}$, whereas the percutaneous exposure to TNF caused prolonged urinary mutagenicity, as can be foreseen when highly lypophilic molecules absorbed in dermal adipose tissue are slowly removed in the blood stream. In both cases however only a negligible amount of the administered dose was excreted in urine in a form which retained mutagenic properties, a phenomenon indicating an effective metabolic deactivation of TNF in vivo (as observed in vitro in the presence of S9) or its binding to macromolecular targets in the body or, in the case of intragastric administration, poor intestinal absorption and massive excretion in feces. This result suggests that, despite the high mutagenic activity exerted by TNF in the test systems applied for its detection in urine concentrates, a low TNF exposure could be undetectable by urinary mutagenicity monitoring. Albeit low, similar levels of TNF exposure could still represent a significant cancer risk in the occupational environment. In fact experimental data argue against the existence of "threshold values" for chemical carcinogens (2). More sophisticated analytical techniques of both environmental and biological monitoring are therefore required to assess the possible occupational risks related to the use of TNF in photocopying and printing systems.

\section{Acknowledgments}

The authors are grateful to Mr U Cervelli and Mr A Calcagnile of the Istituto Superiore di Sanità for their technical assistance.

This work was partially supported by the European Economic Community (contract 530 ENV I-s, project leader A Carere).

\section{References}

1. Ames BN, McCann J, Yamasaki E. Methods for detecting carcinogens and mutagens in the Salmonella/ mammalian-microsome mutagenicity test. Mutat Res 31 (1975) $347-364$.

2. Dunn BP. Wide range linear dose-response curve for DNA binding of orally administred benzo(a)pyrene in mice. Cancer Res 43 (1983) 2654-2658.
3. Falck K, Gröhn P, Sorsa M, Vainio $H$, Heinonen $E$, Holsti LR. Mutagenicity in urine of nurses handling cytostatic drugs. Lancet 1 (1979) 1250-1251.

4. Falck K, Sorsa M, Vainio H, Kilpikari I. Mutagenicity in urine of workers in rubber industry. Mutat Res 79 (1980) 45-52.

5. Gatehouse D. Detection of mutagenic derivatives of cyclophosphamide and a variety of other mutagens in a "microtitre" fluctuation test without microsomal activation. Mutat Res 53 (1978) 289-296.

6. Gatehouse D, Delow GF. The development of a " $m$ icrotitre" fluctuation test for the detection of indirect mutagens, and its use in the evaluation of mixed enzyme induction of the liver. Mutat Res 60 (1979) 239-252.

7. Gibson JF, Baxter PJ, Hedworth-Whitty RB, Gompertz D. Urinary mutagenicity assays: A problem arising from the presence of histidine associated growth factors in XAD-2 prepared urine concentrates, with particular relevance to assays carried out using the bacterial fluctuation test. Carcinogenesis 4 (1983) 1471-1476.

8. Huggins C, Yang NC. Induction and extinction of mammary cancer. Science 137 (1962) 257-262.

9. International Business Machines. Italia S.p.a. - Ente nazionale prevenzione infortuni. Monte Porzio $\mathrm{Ca}$ tone, Roma May 29, 1981. (Doc no 273/81 CH).

10. Kilian DJ, Pullin TG, Connor TH, Legator MS, Edwards HN. Mutagenicity of epichlorohydrin in the bacterial assay system: Evaluation by direct in vitro activity and in vivo activity of urine from exposed humans and mice. Mutat Res 53 (1978) 72.

11. Kriebel D, Commoner B, Bollinger D, Bronsdon A, Gold J, Henry J. Detection of occupational exposure to genotoxic agents with a urinary mutagen assay. Mutat Res 108 (1983) 67-79.

12. Legator MS, Bueding E, Batzinger R, Connor TH, Eisenstadt E, Farrow MG, Ficsor G, Hsie A, Seed J, Stafford RS. An evaluation of the host-mediated assay and body fluid analysis: A report of the US Environmental Protection Agency/Gene Tox Program. Mutat Res 98 (1982) 319-374.

13. Levin DE, Barnes WS, Klekowski E. Mutagenicity of fluorene derivatives: A proposed mechanism. Mutat Res 63 (1979) $1-10$.

14. McCoy EC, Hankel R, Robbins K, Rosenkranz HS, Giuffrida JG, Bizzari DV. Presence of mutagenic substances in the urines of anesthesiologists. Mutat Res 53 (1978) 71.

15. McCoy EC, Rosenkranz EJ, Rosenkranz HS, Mermelstein R. Nitrated fluorene derivatives are potent frameshift mutagens. Mutat Res 90 (1981) 11-20.

16. Probst GS, McMahon RE, Hill LE, Thompson CZ, Epp JK, Neal SB. Chemically induced unsheduled DNA synthesis in primary rats hepatocites cultures: A comparison with bacterial mutagenicity using 218 compounds. Environ Mutagenesis 3 (1981) 11-32.

17. Sorenson WG, Whong WZ, Simpson JP, Brusick DJ, Ong TM. Genotoxic properties of 2,4,7-trinitro-9fluorenone. Mutat Res 118 (1983) 167-176.

i8. Vainio H, Sorsa M, Hemminki K. Biological monitoring in surveillance of exposure to genotoxicant. Am $\mathrm{J}$ Ind Med 4 (1983) 87-103.

Received for publication: 14 December 1984 